\title{
MALAYSIAN ESL STUDENTS' PERCEPTION OF THE IMPORTANCE LEARNING ARGUMENTATIVE WRITING AND CHALLENGES FACED
}

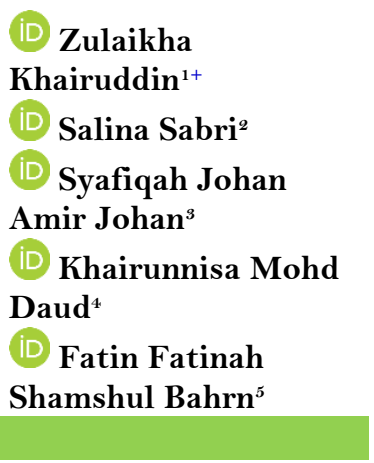

Article History

Received: 24 September 2021 Revised: 20 October 2021 Accepted: 17 November 2021 Published: 9 December 2021

\section{Keywords:}

Argumentative essay

Argumentative writing skills Writing skills

The importance

Challenges

Students' perception

ESL.

\author{
${ }_{1,2,3,1,5}$ Akademi Pengajian Bahasa, Universiti Teknologi MARA, Shah Alam, \\ Selangor, Malaysia. \\ 'Email: zulaikha5497@uitm.edu.my Tel:+60129564817 \\ ${ }^{2}$ Email: salina619@uitm.edu.my Tel: +60195851805 \\ ${ }^{s}$ Email: syafiqah@uitm.edu.my Tel: +60199304551 \\ "Email: khair208@uitm.edu.my Tel: +60127332082 \\ ${ }^{5}$ Email:fatinfatinah@uitm.edu.my Tel: +60173385037
}

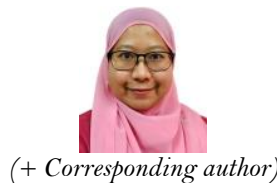

(+ Corresponding author

\begin{abstract}
Although argumentative writing skills are essential for survival in today's social and professional world, they are rather challenging to master. The Malaysian Ministry of Higher Education places great emphasis on the needs for graduates to grasp argumentative writing skills. However, learners appear to be ambivalent about the skills. Thus, using a quantitative approach, this study aims to explore the students' perceptions towards learning argumentative writing as well as identify the challenges that they face. Analysed using ANOVA, data from the questionnaire used in the study indicates that: i) the respondents believed that learning argumentative writing is equally important for academic success and career development in the future; and ii) those with lower grades tend to struggle more with language style and components of argumentative writing. The findings also suggest that educators should try to cater to students' needs in order to promote mastery of argumentative writing skills. In the future, qualitative research could be conducted to explore learners' perceptions in more detail. Researchers could also employ mixed methods to investigate issues around argumentative writing skills from educators' perspectives.
\end{abstract}

Contribution/ Originality: This study contributes to the existing literature to know the importance of learning argumentative writing skills in students' perspective. This study is one of very few studies which have investigated to understand the challenges faced by students in learning argumentative skills.

\section{INTRODUCTION}

\subsection{Background of the Study}

For the development of one's personal and professional lives, it is important that university students learn to argue in a critical, logical, and coherent manner (Andrews, 2000, as cited in Luna, Villalón, Mateos, and Martín (2020)). One way to do this is through learning argumentative writing. Through the right argumentative writing topics, students are able to recognise, unfold, amalgamate, and sort information, which subsequently help them evoke expressions of attitudes (List \& Alexander, 2018). The skills developed through this particular type of writing are part of work-readiness skills especially in anglophone cultures. This clearly shows the importance of argumentative writing to individuals regardless of their fields of study. However, argumentative writing skills are 
considered challenging for students to learn since to write a good argumentative essay, students need to have knowledge of the sentence structure, the format, and the content of the argument (Pratiwi, 2016). This is doubly true for second language (L2) students (Campbell \& Filimon, 2018; Pei, Zheng, Zhang, \& Liu, 2017). Despite the importance of argumentative writing skills, empirical studies related to the perceptions about learning it and challenges faced by Malaysian English as a Second Language (ESL) students during the process of producing this genre of writing are scarce. This study aims to shed light on Malaysian ESL students' perceptions about learning argumentative writing and the challenges they face.

\subsection{Statement of Problem}

The ability to "write arguments to support claims in an analysis of substantive topics or texts using valid reasoning and relevant and sufficient evidence" is listed first under the College and Career Readiness Anchor Standards for Writing of the Common Core, an education standard adopted by 41 states and the District of Columbia in the USA (Common Core, 2021). That this quality is listed first in the standards demonstrates that having good argumentative writing skills is paramount in today's society. In the Malaysian Education Blueprint 2015-2025 (Ministry of Education (MOE), 2015) emphasis is placed on developing students' proficiency in language, including L2 and additional languages, as it is "essential for success in the 21 st century". The document also points out the role of language proficiency in linking "academia and industry" (Ministry of Education (MOE), 2015). Unfortunately, many Malaysian ESL learners seem ambivalent about argumentative writing hence this study aims to explore their perceptions towards learning argumentative writing as well as identify the challenges that they face.

\subsection{Objectives of Study}

The objectives of this study are:

i. To investigate university students' perceptions on the importance of learning argumentative writing.

ii. To identify university students' perceptions on the challenges of learning argumentative writing.

iii. To determine the significant difference between students' year of study and the importance of learning argumentative writing

iv. To investigate the significant difference between students' grades and challenges faced by them

\subsection{Research Questions}

The research questions of this study are:

i. What are university students' perceptions on the importance of learning argumentative writing?

ii. What are university students' perceptions on the challenges of learning argumentative writing?

iii. Is there any significant difference between students' year of study and the importance of learning argumentative writing?

iv. Is there any significant difference between students' grades and challenges faced by them?

\section{LITERATURE REVIEW}

Argumentative writing is a structured piece of writing that presents one's point of view. Having a good command of argumentative writing skill would command readers' belief and trust, thereby benefitting the writers (Lam, Hew, \& Chiu, 2018). Making an argument "entails making a case to sustain a claim, identifying supporting evidence from multiple sources that connects the claim logically, using warrants that support the link between the claim and the supporting evidence, and backing the warrants with support" (Hillocks, 2011, as cited in Campbell and Filimon (2018)). These can be structured in many ways, the most common being the three essential parts: the attention-getting introduction; the body paragraph where the writer actually proves the assertion; and a 
conclusion (Bayu, 2019). In a study by (Nejmaoui, 2019) the four skills that are important in an argumentative writing were identified and these four skills are: i) constructing a valid argument, ii) evaluating an alternative thesis, iii) detecting the credibility of sources, and iv) assessing the relevance of evidence.

Apart from these skills, one of the most important characteristics that students, or any individual embarking on an argumentative writing, must note is that this type of writing is very genre- and audience-specific. An argumentative writer must be able to shift from knowledge-telling to knowledge-transforming, deliver their content to the audience, and have their content understood, all of which are rather daunting tasks, especially for students (Morris et al., 2018). To write a well-developed piece of argumentative writing, students need to have good fundamentals of academic language, i.e. a language that is very discipline-specific in terms of its vocabulary, grammar, and even punctuation (Taylor, Lawrence, Connor, \& Snow, 2018). Newell et al. (2011, as cited in Campbell and Filimon (2018)) defined argumentative reading and writing as:

“...involving identification of a thesis or a claim, (also called a claim), supportive evidence (empirical or experiential), and assessment of warrants connecting the thesis, evidence, and situation constituting an argument. In contrast to simply attempting to persuade someone to believe or do something, evidencebased argumentation involves making a claim supported by reasons or evidence from multiple sources that connects to the claim in a principled way".

Clearly, these are not skills that could be learnt overnight so even writers who are already quite proficient in the target language may face difficulties when writing an argumentative essay (Morris et al., 2018).

A number of studies have shown that students face various challenges in argumentative writing. Studying the writing of 138 Social Sciences students at Finnish Open University, Hyytinen, Löfström, and Lindblom-Ylänne (2016) identified three main challenges in writing an argumentative essay and these problems are: i) unclear argumentation, ii) isolated facts, and iii) incorrect arguments/fallacies. Miller and Pessoa (2016) study on 83 students of first year World History course at a branch campus of an English-medium American university in the Middle East found that if students are clear of the organisational structures and features of an argumentative writing, i.e. the thesis statement and the topic sentence(s), they would be able to overcome the challenges and in turn produce well-written argumentation. Latifi, Noroozi, Hatami, and Biemans (2021) outlined several reasons students face challenges in argumentative writing, and these reasons are: i) lacking knowledge of the characteristics of a good argumentative essay, ii) struggling to write a cohesive argumentative essay, and iii) struggling to understand the terms and jargon used in specific argumentative essays.

In addition, first language (L1) interference might also hinder students' ability to compose strong argumentative writing pieces. Pei et al. (2017) who conducted a study on 132 Chinese students majoring in English, and Tahira and Haider (2019) who interviewed three foreign students enrolled in the MA English Language Teaching and Applied Linguistics at King's College in London, note that differences in the critical thinking styles and writing conventions of students' first and second languages may pose a challenge to L2 students when writing argumentative writing. Thus, students would benefit by getting exposure from engaging in social dialogues and discussions because such exposure could potentially lead to the students stimulating, formulating, and challenging their ideas among peers (Reznitskaya et al., 2001). Furthermore, as a writer needs to understand the content in order to craft strong, coherent, and clear arguments, Shi, Matos, and Kuhn (2019) suggested a dialogic approach among peers to enhance their argumentative skills. Even though the dialogic approach is more of a conversational activity, the skills applied in the spoken discourse are likely to be highly beneficial when applied to writing argumentative essays. This is because in the dialogic approach, speakers argue and defend their points and in turn develop their critical thinking skills, which undoubtedly are crucial in writing an argumentative essay. For these reasons, there is a need to understand Malaysian ESL students' perception of learning argumentative writing as well as the challenges that they face. 


\section{METHODOLOGY}

This study employed a quantitative approach and followed a descriptive research design. The instrument used in this study was a questionnaire that was adapted from Cai (2013). There were five parts in the questionnaire with 13 items in total. Part A focussed on demographic details while part B investigated motives for learning argumentative writing. Part $\mathrm{C}$ looked to understand the challenges in learning argumentative writing. Fourthly, part D surveyed respondents' past learning experience and lastly, part E examined their future hopes for argumentative writing. The population of this study was students from one of the public universities in Malaysia and from the population, there were 101 students who participated in this study. However, only 96 responses could be used after cleaning the data. The respondents were given around 2 weeks to complete the questionnaire, and 101 usable responses were collected. The data, analysed via SPSS v27, is portrayed in the form of tables. The data is reported in percentage, frequency, mean, and standard deviation.

\section{FINDINGS}

RQ 1: What are university students' perceptions on the importance of learning argumentative writing?

Table-1. Students' perceptions on the importance of learning argumentative writing skills.

\begin{tabular}{l|c|c}
\hline & Mean & Std. Deviation \\
\hline How important do you think argumentative writing skills are to your studies? & 4.29 & 0.724 \\
\hline $\begin{array}{l}\text { How important do you think argumentative writing skills are to your future } \\
\text { career? }\end{array}$ & 4.11 & 0.869 \\
\hline How important is having your academic work published during your study? & 3.76 & 1.003 \\
\hline Importance of learning argumentative writing skills & 4.06 & 0.645 \\
\hline
\end{tabular}

Table 1 displays students' perceptions towards the importance of learning argumentative writing skills. The highest mean score is obtained by 'How important do you think argumentative writing skills are to your studies?' with a mean score of $4.29(\mathrm{SD}=0.724)$ followed by 'How important do you think argumentative writing skills are to your future career?' with the mean score of $(\mathrm{M}=4.11, \mathrm{SD}=0.8699)$. Lastly, the mean score of 'How important is having your academic work published during your study?' is $3.76(\mathrm{SD}=1.003)$. Overall mean score for 'Importance of Learning Argumentative Writing' is $(\mathrm{M}=4.06$; $\mathrm{SD}=0.645)$. Based on these results, it shows that students perceived learning argumentative writing skills is important. However, they viewed it as being more important for their immediate needs than in the future.

RQ 2: What are university students' perceptions on the challenges of learning argumentative writing skills?

Table-2. Students' perceptions on the language style in an argumentative writing.

\begin{tabular}{l|c|c}
\hline & Mean & Std. Deviation \\
\hline Using appropriate lexical phrases freely to build up the sentences and paragraphs & 2.91 & 0.859 \\
\hline Using proper argumentative writing language and vocabulary style & 2.96 & 0.893 \\
\hline $\begin{array}{l}\text { Using proper grammar such as correct tenses, subject-verb agreement, and } \\
\text { reporting verbs }\end{array}$ & 2.76 & 0.891 \\
\hline Language style in an argumentative writing & 2.87 & 0.724 \\
\hline
\end{tabular}

Table 2 shows students' perceptions on the language style in an argumentative writing. The least mean score is obtained by 'Using proper grammar such as correct tenses, subject-verb agreement, and reporting verbs' with the mean score of $2.76(\mathrm{SD}=0.891)$. Next, the mean scores for 'Using appropriate lexical phrases freely to build up the sentences and paragraphs' and 'Using proper argumentative writing language and vocabulary style' are $(\mathrm{M}=2.91$, $\mathrm{SD}=0.8593 ; \mathrm{M}=2.96, \mathrm{SD}=0.893)$ respectively. Overall mean score for 'Language style in an argumentative writing' is $2.87(\mathrm{SD}=0.724)$. This indicates that students presumed that they did not face any problem in applying the correct language style in their argumentative writing. 
Table-3. Students' perceptions on the organisational structure of an argumentative writing.

\begin{tabular}{l|c|c}
\hline & Mean & Std. Deviation \\
\hline Summarising & 2.78 & 0.784 \\
\hline Paraphrasing & 2.80 & 0.936 \\
\hline Writing coherent paragraphs & 2.95 & 0.851 \\
\hline Linking sentences smoothly & 2.66 & 0.819 \\
\hline Organisational structure of an argumentative writing & 2.80 & 0.690 \\
\hline
\end{tabular}

Table 3 exhibits students' perceptions on the organisational structure of an argumentative writing. The lowest mean score is obtained by 'Linking sentences smoothly' with the mean score of $2.66(\mathrm{SD}=0.819)$. Next, the mean scores for 'Summarising' and 'Paraphrasing' are $(\mathrm{M}=2.78, \mathrm{SD}=0.784 ; \mathrm{M}=2.80, \mathrm{SD}=0.936)$ respectively. The highest mean score is obtained by 'Writing coherent paragraphs' with the mean score of $2.95(\mathrm{SD}=0.851)$. The overall mean score for 'Organisational structure of an argumentative writing' is $2.80(\mathrm{SD}=0.690)$. Based on the results, it can be inferred that students perceived that they did not have issues in terms of following the organisational structure of an argumentative writing.

Table-4. Students' perceptions on the components of an argumentative writing.

\begin{tabular}{|c|c|c|}
\hline & Mean & Std. Deviation \\
\hline Writing introductions & 2.49 & 0.833 \\
\hline Searching for appropriate literature using databases and library resources & 3.25 & 0.984 \\
\hline Referring to sources & 2.95 & 0.875 \\
\hline Reviewing and critiquing the previous research and creating a research gap & 3.72 & 0.879 \\
\hline Writing references/bibliography & 2.34 & 1.024 \\
\hline Writing conclusions & 2.60 & 0.957 \\
\hline Proof-reading & 2.85 & 0.973 \\
\hline Components of an argumentative writing & 2.91 & 0.564 \\
\hline
\end{tabular}

Table 4 presents students' perceptions on the components of argumentative writing. The lowest mean score is obtained by 'Writing references/bibliography' with the mean score of 2.34 (SD=1.024) and followed by 'Writing introductions', 'Writing conclusions', and 'Referring to sources' with the mean scores of $(\mathrm{M}=2.49, \mathrm{SD}=0.833$; $\mathrm{M}=2.60, \mathrm{SD}=.957 ; \mathrm{M}=2.95, \mathrm{SD}=0.875)$ respectively. Next, 'Proof-reading' obtains the mean score of 2.85 $(\mathrm{SD}=0.973)$. The highest mean score is obtained by 'Reviewing and critiquing the previous research and creating a research gap' with the mean score of $3.72(\mathrm{SD}=0.879)$. The mean score for 'Searching for appropriate literature using databases and library resources' is $(\mathrm{M}=3.25, \mathrm{SD}=0.984)$. The overall mean score for 'Components of an argumentative writing' is $2.91(\mathrm{SD}=0.564)$. This shows that the students did not perceive the components of argumentative writing as much of an issue.

Table-5. The importance of learning argumentative writing skills according to semester.

\begin{tabular}{|c|c|c|c|c|c|c|c|c|}
\hline & \multirow{2}{*}{$\mathbf{N}$} & \multirow{2}{*}{ Mean } & \multirow{2}{*}{$\begin{array}{l}\text { Std. } \\
\text { Deviation }\end{array}$} & \multirow{2}{*}{$\begin{array}{l}\text { Std. } \\
\text { Error }\end{array}$} & \multicolumn{2}{|c|}{$\begin{array}{c}\text { 95\% Confidence Interval for } \\
\text { Mean }\end{array}$} & \multirow[t]{2}{*}{ Minimum } & \multirow[t]{2}{*}{ Maximum } \\
\hline & & & & & $\begin{array}{l}\text { Lower } \\
\text { Bound }\end{array}$ & Upper Bound & & \\
\hline Semester 3 & 21 & 3.97 & 0.682 & 0.149 & 3.66 & 4.28 & 3 & 5 \\
\hline Semester 4 & 26 & 4.18 & 0.583 & 0.114 & 3.94 & 4.41 & 3 & 5 \\
\hline Semester 5 & 49 & 4.03 & 0.663 & 0.095 & 3.84 & 4.22 & 2 & 5 \\
\hline Total & 96 & 4.06 & 0.645 & 0.066 & 3.92 & 4.19 & 2 & 5 \\
\hline
\end{tabular}

Table 5 shows the importance of learning argumentative writing skills as perceived by students of different semesters. The mean score obtained by Semester 3 is $3.97(\mathrm{SD}=0.682)$. Semester 4 students obtained the highest 
mean score which is 4.18 with standard deviation of (0.583). Last but not least, the mean score for Semester 5 students is $4.03(\mathrm{SD}=0.663)$. Overall mean score is $4.06(\mathrm{SD}=0.654)$.

Table-6. ANOVA of students' perceptions towards the importance of learning argumentative writing skills.

\begin{tabular}{l|c|c|c|c|c}
\hline & Sum of Squares & df & Mean Square & F & Sig. \\
\hline Between Groups & 0.599 & 2 & 0.299 & 0.716 & 0.491 \\
\hline Within Groups & 38.883 & 93 & 0.418 & & \\
\hline Total & 39.481 & 95 & & & \\
\hline
\end{tabular}

Table 6 depicts the difference of students' perceptions towards the importance of learning argumentative writing skills between the different semesters (Semesters 3, 4, and 5). This table shows that there is a difference in their perceptions towards the importance of learning argumentative writing skills. To determine if there are significant differences in these scores, One-Way ANOVA was conducted. The ANOVA analysis suggests that there is no significant difference $[\mathrm{F}(2,93)=0.716]$ in these scores at the 0.05 level.

Table-7. LSD of students' perceptions towards the importance of learning argumentative writing skills.

\begin{tabular}{l|c|c|c|c|c|c}
\hline $\begin{array}{l}(\mathbf{I}) \\
\text { Semester }\end{array}$ & $\begin{array}{c}(\mathbf{J}) \\
\text { Semester }\end{array}$ & $\begin{array}{c}\text { Mean Difference } \\
(\mathbf{I}-\mathbf{J})\end{array}$ & Std. Error & Sig. & \multicolumn{2}{|c}{$\begin{array}{c}\text { 95\% Confidence } \\
\text { Interval }\end{array}$} \\
\cline { 5 - 7 } & & & & & Lower Bound & Upper Bound \\
\hline Semester 3 & Semester 4 & -0.211 & 0.190 & 0.268 & -0.59 & 0.17 \\
\cline { 2 - 6 } & Semester 5 & -0.059 & 0.169 & 0.727 & -0.39 & 0.28 \\
\hline Semester 4 & Semester 5 & 0.152 & 0.157 & 0.334 & -0.16 & 0.46 \\
\hline
\end{tabular}

Table 7 shows that there is no significant difference between Semesters 3 and 4, Semesters 3 and 5, and Semesters 4 and 5 since their p values are more than 0.05. Based on these results, it can be said that the majority of the students believed that learning argumentative writing skills is important for their studies.

Table-8. Perceived views on language style.

\begin{tabular}{|c|c|c|c|c|c|c|c|c|}
\hline & \multirow[t]{2}{*}{$\mathbf{N}$} & \multirow[t]{2}{*}{ Mean } & \multirow[t]{2}{*}{$\begin{array}{c}\text { Std. } \\
\text { Deviation }\end{array}$} & \multirow[t]{2}{*}{$\begin{array}{l}\text { Std. } \\
\text { Error }\end{array}$} & \multicolumn{2}{|c|}{$\begin{array}{l}\text { 95\% Confidence Interval } \\
\text { for Mean }\end{array}$} & \multirow[t]{2}{*}{ Minimum } & \multirow[t]{2}{*}{ Maximum } \\
\hline & & & & & Lower Bound & $\begin{array}{l}\text { Upper } \\
\text { Bound }\end{array}$ & & \\
\hline $\mathrm{A}+$ & 4 & 2.08 & 0.957 & 0.479 & 0.56 & 3.61 & 1 & 3 \\
\hline $\mathrm{A}$ & 15 & 2.44 & 0.613 & 0.158 & 2.11 & 2.78 & 1 & 3 \\
\hline A- & 18 & 2.80 & 0.617 & 0.145 & 2.49 & 3.10 & 2 & 4 \\
\hline $\mathrm{B}+$ & 38 & 3.02 & 0.671 & 0.109 & 2.80 & 3.24 & 1 & 4 \\
\hline $\mathrm{B}$ & 15 & 3.13 & 0.862 & 0.223 & 2.66 & 3.61 & 1 & 5 \\
\hline B- & 6 & 3.17 & 0.350 & 0.143 & 2.80 & 3.53 & 3 & 4 \\
\hline Total & 96 & 2.88 & 0.724 & 0.074 & 2.73 & 3.02 & 1 & 5 \\
\hline
\end{tabular}

Table 8 shows the descriptive statistics for perceived views on language style. The lowest mean score of 2.08 $(\mathrm{SD}=0.957)$ was obtained by 'A+' students followed by 'A' and 'A-' $(\mathrm{M}=2.44, \mathrm{SD}=0.613 ; \mathrm{M}=2.80, \mathrm{SD}=0.617)$ respectively. Students with 'B+' obtained the mean score of $3.02(\mathrm{SD}=0.671)$ and those with 'B' obtained the mean score of $3.13(\mathrm{SD}=0.862)$. The mean score obtained by 'B-' students is $3.17(\mathrm{SD}=0.350)$. The overall mean score is $(\mathrm{M}=2.88, \mathrm{SD} 0.724)$.

Table-9. ANOVA of perceived views on language style.

\begin{tabular}{l|c|c|c|c|c}
\hline & $\begin{array}{c}\text { Sum of } \\
\text { Squares }\end{array}$ & df & $\begin{array}{c}\text { Mean } \\
\text { Square }\end{array}$ & F & Sig. \\
\hline Between Groups & 7.683 & 5 & 1.537 & 3.281 & 0.009 \\
\hline Within Groups & 42.151 & 90 & 0.468 & & \\
\hline Total & 49.833 & 95 & & & \\
\hline
\end{tabular}


Based on Table 9, to determine if there are significant differences in these scores, One-Way ANOVA was conducted. The ANOVA analysis depicts that there is a significant difference $[\mathrm{F}(4,90)=3.281]$ in these scores at the 0.05 level.

Table-10. LSD of perceived views on language style.

\begin{tabular}{|c|c|c|c|c|c|c|}
\hline \multirow[t]{2}{*}{ (I) Grade } & \multirow[t]{2}{*}{$(\mathrm{J})$ Grade } & \multirow{2}{*}{$\begin{array}{c}\text { Mean Difference } \\
(\mathrm{I}-\mathrm{J})\end{array}$} & \multirow{2}{*}{$\begin{array}{l}\text { Std. } \\
\text { Error }\end{array}$} & \multirow[t]{2}{*}{ Sig. } & \multicolumn{2}{|c|}{ 95\% Confidence Interval } \\
\hline & & & & & Lower Bound & Upper Bound \\
\hline \multirow[t]{5}{*}{$\mathrm{A}+$} & A & -0.361 & 0.385 & 0.351 & -1.13 & 0.40 \\
\hline & A- & -0.713 & 0.378 & 0.063 & -1.46 & 0.04 \\
\hline & $\mathrm{B}+$ & $-0.934^{*}$ & 0.360 & 0.011 & -1.65 & -0.22 \\
\hline & $\mathrm{B}$ & $-1.050^{*}$ & 0.385 & 0.008 & -1.82 & -0.28 \\
\hline & B- & $-1.083^{*}$ & 0.442 & 0.016 & -1.96 & -0.21 \\
\hline \multirow[t]{4}{*}{$\mathrm{A}$} & A- & -0.352 & 0.239 & 0.145 & -0.83 & 0.12 \\
\hline & $\mathrm{B}+$ & $-0.573^{*}$ & 0.209 & 0.007 & -0.99 & -0.16 \\
\hline & $\mathrm{B}$ & $-0.689^{*}$ & 0.250 & 0.007 & -1.19 & -0.19 \\
\hline & B- & $-0.722^{*}$ & 0.331 & 0.032 & -1.38 & -0.07 \\
\hline \multirow[t]{3}{*}{ A- } & $\mathrm{B}+$ & -0.221 & 0.196 & 0.262 & -0.61 & 0.17 \\
\hline & $\mathrm{B}$ & -0.337 & 0.239 & 0.162 & -0.81 & 0.14 \\
\hline & B- & -0.370 & 0.323 & 0.254 & -1.01 & 0.27 \\
\hline \multirow[t]{2}{*}{$\mathrm{B}+$} & $\mathrm{B}$ & -0.116 & 0.209 & 0.580 & -0.53 & 0.30 \\
\hline & B- & -0.149 & 0.301 & 0.621 & -0.75 & 0.45 \\
\hline B & B- & -0.033 & 0.331 & 0.920 & -0.69 & 0.62 \\
\hline
\end{tabular}

Table 10 shows that there is a significant difference between students who obtained 'A+' and 'B+', 'A+' and 'B', and 'A+' and 'B-' with ( $\mathrm{p}=0.011,0.008$, and 0.016$)$ respectively. There is also a significant difference between 'A' and ' $\mathrm{B}+$ ' and ' $\mathrm{B}$ ' with $\mathrm{p}=0.07$. Lastly, the $\mathrm{p}$ value for ' $\mathrm{A}$ ' and ' $\mathrm{B}-$ ' is $(0.032)$ which indicates that there is significant difference between these groups of students. In other words, the 'A' students perceived that they experienced less difficulties in terms of language problems. This means that there is a difference among students who obtained different grades. Based on the results, it can be said that students generally perceived that they did not have issues or problems with the language style of an argumentative writing.

Table-11. Perceived views on the organisational structure.

\begin{tabular}{|c|c|c|c|c|c|c|c|c|}
\hline & \multirow[t]{2}{*}{$\mathbf{N}$} & \multirow[t]{2}{*}{ Mean } & \multirow{2}{*}{$\begin{array}{l}\text { Std. } \\
\text { Deviation }\end{array}$} & \multirow{2}{*}{$\begin{array}{l}\text { Std. } \\
\text { Error }\end{array}$} & \multicolumn{2}{|c|}{$\begin{array}{c}\text { 95\% Confidence Interval for } \\
\text { Mean }\end{array}$} & \multirow[t]{2}{*}{ Minimum } & \multirow[t]{2}{*}{ Maximum } \\
\hline & & & & & Lower Bound & Upper Bound & & \\
\hline$\overline{A+}$ & 4 & 2.38 & 0.924 & 0.462 & 0.90 & 3.85 & 1 & 3 \\
\hline A & 15 & 2.47 & 0.654 & 0.169 & 2.10 & 2.83 & 2 & 4 \\
\hline A- & 18 & 2.69 & 0.730 & 0.172 & 2.33 & 3.06 & 2 & 4 \\
\hline $\mathrm{B}+$ & 38 & 2.99 & 0.580 & 0.094 & 2.80 & 3.18 & 2 & 5 \\
\hline $\mathrm{B}$ & 15 & 2.82 & 0.868 & 0.224 & 2.34 & 3.30 & 1 & 5 \\
\hline B- & 6 & 2.92 & 0.342 & 0.139 & 2.56 & 3.28 & 2 & 3 \\
\hline Total & 96 & 2.80 & 0.690 & 0.070 & 2.66 & 2.94 & 1 & 5 \\
\hline
\end{tabular}

Table 11 illustrates the descriptive statistics for perceived views on the organisational structure. The mean scores obtained by 'A+', 'A', and 'A-' students are ( $\mathrm{M}=2.38, \mathrm{SD}=.924 ; \mathrm{M}=2.47, \mathrm{SD}=.654 ; \mathrm{M}=2.69, \mathrm{SD}=0.730)$, respectively. The mean score for 'B+' students is $2.99(\mathrm{SD}=0.580)$ followed by ' $\mathrm{B}$ ' students with the mean score of 2.82 ( $\mathrm{SD}=0.868)$. Lastly, 'B-' students obtain the mean score of $2.92(\mathrm{SD}=0.342)$. The overall mean score for perceived views on the organisational structure is $2.80(\mathrm{SD}=0.690)$. 
Table-12. ANOVA of perceived views on the organisational structure.

\begin{tabular}{l|c|c|c|c|c}
\hline & Sum of Squares & df & Mean Square & F & Sig. \\
\hline Between Groups & 4.096 & 5 & 0.819 & 1.790 & 0.123 \\
\hline Within Groups & 41.193 & 90 & 0.458 & & \\
\hline Total & 45.289 & 95 & & & \\
\hline
\end{tabular}

Based on Table 12, to determine if there are significant differences in these scores, One-Way ANOVA was conducted. The ANOVA analysis depicts that there is no significant difference $[\mathrm{F}(5,90)=1.790]$ in these scores at the 0.05 level.

Table-13. LSD of perceived views on the organisational structure.

\begin{tabular}{|c|c|c|c|c|c|c|}
\hline \multirow{2}{*}{ (I) Grade } & \multirow{2}{*}{$\begin{array}{c}(\mathrm{J}) \\
\text { Grade }\end{array}$} & \multirow{2}{*}{$\begin{array}{c}\text { Mean } \\
\text { Difference }(\mathbf{I}-\mathbf{J})\end{array}$} & \multirow{2}{*}{$\begin{array}{l}\text { Stdo. } \\
\text { Error }\end{array}$} & \multirow{2}{*}{ Sigo. } & \multicolumn{2}{|c|}{ 95\% Confidence Interval } \\
\hline & & & & & Lower Bound & Upper Bound \\
\hline \multirow{5}{*}{$A+$} & $\mathrm{A}$ & -0.092 & 0.381 & 0.810 & -0.85 & 0.66 \\
\hline & A- & -0.319 & 0.374 & 0.395 & -1.06 & 0.42 \\
\hline & $\mathrm{B}+$ & -0.618 & 0.356 & 0.085 & -1.32 & 0.09 \\
\hline & $\mathrm{B}$ & -0.442 & 0.381 & 0.249 & -1.20 & 0.31 \\
\hline & B- & -0.542 & 0.437 & 0.218 & -1.41 & 0.33 \\
\hline \multirow{4}{*}{$\mathrm{A}$} & A- & -0.228 & 0.237 & 0.338 & -0.70 & 0.24 \\
\hline & $\mathrm{B}+$ & $-0.527^{*}$ & 0.206 & 0.012 & -0.94 & -0.12 \\
\hline & $\mathrm{B}$ & -0.350 & 0.247 & 0.160 & -0.84 & 0.14 \\
\hline & B- & -0.450 & 0.327 & 0.172 & -1.10 & 0.20 \\
\hline \multirow{3}{*}{ A- } & $\mathrm{B}+$ & -0.299 & 0.194 & 0.126 & -0.68 & 0.09 \\
\hline & $\mathrm{B}$ & -0.122 & 0.237 & 0.607 & -0.59 & 0.35 \\
\hline & B- & -0.222 & 0.319 & 0.488 & -0.86 & 0.41 \\
\hline \multirow{2}{*}{$\mathrm{B}+$} & $\mathrm{B}$ & 0.177 & 0.206 & 0.394 & -0.23 & 0.59 \\
\hline & B- & 0.077 & 0.297 & 0.797 & -0.51 & 0.67 \\
\hline $\mathrm{B}$ & B- & -0.100 & 0.327 & 0.760 & -0.75 & 0.55 \\
\hline
\end{tabular}

Based on Table 13, there is a significant difference between students who obtained 'A' and those who obtained 'B+' with $(\mathrm{p}=0.012)$ at the 0.05 level. This means that the majority of students indicated that they did not have any problems with the organisational structure of an argumentative writing.

Table-14. Perceived views on the components of argumentative writing.

\begin{tabular}{|c|c|c|c|c|c|c|c|c|}
\hline & \multirow[t]{2}{*}{$\mathbf{N}$} & \multirow[t]{2}{*}{ Mean } & \multirow{2}{*}{$\begin{array}{c}\text { Std. } \\
\text { Deviation }\end{array}$} & \multirow{2}{*}{$\begin{array}{l}\text { Std. } \\
\text { Error }\end{array}$} & \multicolumn{2}{|c|}{$\begin{array}{c}\text { 95\% Confidence Interval for } \\
\text { Mean }\end{array}$} & \multirow[t]{2}{*}{ Minimum } & \multirow[t]{2}{*}{ Maximum } \\
\hline & & & & & Lower Bound & Upper Bound & & \\
\hline $\mathrm{A}+$ & 4 & 2.22 & 0.664 & 0.332 & 1.16 & 3.28 & 1 & 3 \\
\hline $\mathrm{A}$ & 15 & 2.71 & 0.455 & 0.117 & 2.46 & 2.96 & 2 & 3 \\
\hline A- & 18 & 2.83 & 0.623 & 0.147 & 2.52 & 3.14 & 2 & 4 \\
\hline $\mathrm{B}+$ & 38 & 3.07 & 0.532 & 0.086 & 2.89 & 3.24 & 2 & 4 \\
\hline $\mathrm{B}$ & 15 & 2.95 & 0.599 & 0.155 & 2.62 & 3.28 & 2 & 4 \\
\hline B- & 6 & 3.00 & 0.209 & 0.085 & 2.78 & 3.22 & 3 & 3 \\
\hline Total & 96 & 2.91 & 0.564 & 0.058 & 2.80 & 3.02 & 1 & 4 \\
\hline
\end{tabular}

Table 14 demonstrates the descriptive statistics of students' perceived views on the components of argumentative writing. The highest mean score is obtained by ' $\mathrm{B}+$ ' $(\mathrm{M}=3.07 ; \mathrm{SD}=0.532)$, followed by 'B-' $(\mathrm{M}=3.00$; $\mathrm{SD}=0.209)$. The mean scores for 'B', 'A-', and 'A' are $2.95(\mathrm{SD}=0.599), 2.83(\mathrm{SD}=0.623)$, and $2.71(\mathrm{SD}=0.455)$, respectively. The least mean score is obtained by 'A+' $(\mathrm{M}=2.22, \mathrm{SD}=0.664)$. The overall mean score for perceived views on the components of argumentative writing is 2.91 ( $\mathrm{SD}=0.564)$. To determine if there are significant differences in these scores, One-Way ANOVA was conducted. The ANOVA analysis depicts that there is a significant difference $[\mathrm{F}(5,90)=2.482]$ in these scores at the 0.05 level. 
Table-15. ANOVA of perceived views on the components of argumentative writing.

\begin{tabular}{c|c|c|c|c|c}
\hline & Sum of Squares & df & Mean Square & F & Sig. \\
\hline Between Groups & 3.661 & 5 & 0.732 & 2.482 & 0.037 \\
\hline Within Groups & 26.548 & 90 & 0.295 & & \\
\hline Total & 30.209 & 95 & & & \\
\hline
\end{tabular}

Based on Table 15, to determine if there are significant differences in these scores, One-Way ANOVA was conducted. The ANOVA analysis depicts that there is a significant difference $[\mathrm{F}(5,90)=2.482]$ in these scores at the 0.05 level.

Table-16. LSD of perceived views on the components of argumentative writing.

\begin{tabular}{|c|c|c|c|c|c|c|}
\hline \multirow[t]{2}{*}{ (I) Grade } & \multirow[t]{2}{*}{ (J) Grade } & \multirow[t]{2}{*}{ Mean Difference (I-J) } & \multirow[t]{2}{*}{ Std. Error } & \multirow[t]{2}{*}{ Sig. } & \multicolumn{2}{|c|}{ 95\% Confidence Interval } \\
\hline & & & & & $\begin{array}{l}\text { Lower } \\
\text { Bound }\end{array}$ & Upper Bound \\
\hline \multirow[t]{5}{*}{$\mathrm{A}+$} & $\mathrm{A}$ & -0.490 & 0.306 & 0.113 & -1.10 & 0.12 \\
\hline & A- & $-0.615^{*}$ & 0.300 & 0.044 & -1.21 & -0.02 \\
\hline & $\mathrm{B}+$ & $-0.850^{*}$ & 0.285 & 0.004 & -1.42 & -0.28 \\
\hline & $\mathrm{B}$ & $-0.731^{*}$ & 0.306 & 0.019 & -1.34 & -0.12 \\
\hline & B- & $-0.781^{*}$ & 0.351 & 0.028 & -1.48 & -0.08 \\
\hline \multirow[t]{4}{*}{$\mathrm{A}$} & A- & -0.125 & 0.190 & 0.512 & -0.50 & 0.25 \\
\hline & $\mathrm{B}+$ & $-0.361^{*}$ & 0.166 & 0.032 & -0.69 & -0.03 \\
\hline & $\mathrm{B}$ & -0.242 & 0.198 & 0.226 & -0.64 & 0.15 \\
\hline & B- & -0.292 & 0.262 & 0.269 & -0.81 & 0.23 \\
\hline \multirow[t]{3}{*}{ A- } & $\mathrm{B}+$ & -0.236 & 0.155 & 0.133 & -0.54 & 0.07 \\
\hline & B & -0.117 & 0.190 & 0.540 & -0.49 & 0.26 \\
\hline & B- & -0.167 & 0.256 & 0.517 & -0.68 & 0.34 \\
\hline \multirow[t]{2}{*}{$\mathrm{B}+$} & $\mathrm{B}$ & 0.119 & 0.166 & 0.474 & -0.21 & 0.45 \\
\hline & B- & 0.069 & 0.239 & 0.773 & -0.40 & 0.54 \\
\hline B & B- & -0.050 & 0.262 & 0.849 & -0.57 & 0.47 \\
\hline
\end{tabular}

Table 16 shows that there is a significant difference between 'A+' and 'A-', 'A+' and 'B+', 'A+' and 'B', and A+' and 'B-' with $\mathrm{p}$ value $(\mathrm{p}=0.044,0.004,0.019$, and 0.028$)$, respectively. There is also a significant difference between 'A' and ' $\mathrm{B}+$ ' with $\mathrm{p}<0.05$. This result shows that students indicated that they did not face any challenges in applying the components of argumentative writing.

\section{CONCLUSION}

\subsection{Summary of Findings}

Based on the results of the current study, students across all semesters believed that learning argumentative writing is equally important for academic success and career development in the future. This suggests that learning argumentative writing skills can help bridge the gap between the education system and industry needs as outlined in the Malaysian Education Blueprint 2015-2025 (Ministry of Education (MOE), 2015). As the study was conducted among English majors with relatively advanced levels of L2, most of the students believed that they did not have difficulties with argumentative writing. This perception differs depending on their grade, and those with lower grades tend to struggle more with language style and components of argumentative writing such as introduction and bibliography. This is in line with the findings that suggest novice writers who have little knowledge of how to write a good argumentative essay would face difficulties in terms of linguistic competence (vocabulary, grammar, and coherence), background knowledge, organisation and development of an argumentative essay, and critical thinking skills (Dang, Chau, \& Tra, 2020; Rubiaee, Darus, \& Abu Bakar, 2019). 


\subsection{Pedagogical Implications}

This study shows that most students understand that argumentative writing is important and beneficial for their future career. Based on the results, the majority of the students perceived that they do not have problems in argumentative writing as they were from an English-major programme. However, to avoid some students from being left behind, educators still need to be aware of the small number of students who may face difficulties in writing argumentative essays, especially as those with lower grades attest to struggling a little more than their higher-achieving counterparts. One suggestion would be to identify the students in order to help them in a focus group. Educators should also identify challenges faced by the students so they could cater to the students' needs by adapting their teaching style in the classroom and providing scaffolding for them in an unthreatening environment.

\subsection{Suggestions for Future Research}

For future research, researchers could utilise qualitative approach by interviewing and observing the students while they are writing argumentative essays. This is to get in-depth information, so that the future researchers could validate the current study. Future research could also look into educator's perspective in teaching argumentative writing and investigate challenges faced by them. For a more rigorous result, the research can also be done using both qualitative and quantitative approaches (i.e. mixed methods). Findings of this study should also be treated with caution as the respondents, who are majoring in English, have a higher level of L2 than the average Malaysian student. In the future, this study can be replicated with students of different majors, proficiency levels, and even educational levels (i.e. primary and secondary). Besides determining whether proficiency levels of students have an impact on how challenging they find argumentative writing, the replication studies can also ascertain whether all Malaysian students place the same level of importance on learning argumentative writing skills. Future studies may also look into which elements students lack or have difficulties with and how educators can employ suitable teaching methods to help students address those issues. Furthermore, future replications can confirm findings by Srinawati and Alwi (2020) that learning argumentative writing skills could help learners improve and enhance their critical thinking. These suggestions could help both students and educators understand each other's struggles in teaching and learning argumentative writing. These suggestions could also contribute to pedagogical implications in the future.

Funding: This study received no specific financial support.

Competing Interests: The authors declare that they have no competing interests.

Acknowledgement: All authors contributed equally to the conception and design of the study.

\section{REFERENCES}

Bayu, R. (2019). Writing argumentative essay: How far they can go? Journal of Research and Innovation in Language, 1(2), 6167.Available at: https://doi.org/10.31849/reila.v1i2.2966.

Cai, L. J. (2013). Students' perceptions of academic writing: A needs analysis of EAP in China. Journal of Language Education in Asia, 4(1), 5-22.Available at: http://dx.doi.org/10.5746/LEiA/13/V4/I1/A2/Cai.

Campbell, Y. C., \& Filimon, C. (2018). Supporting the argumentative writing of students in linguistically diverse classrooms: An action research study. Research in Middle Level Education, 41(1), 1-10.Available at: https://doi.org/10.1080/19404476.2017.1402408.

Common Core. (2021). English language arts standards » anchor standards » college and career readiness anchor standards for writing. Retrieved from http://www.corestandards.org/ELA-Literacy/CCRA/W/.

Dang, T. H., Chau, T. H., \& Tra, T. Q. (2020). A study on the difficulties in writing argumentative essays of English-majored sophomores at Tay Do university, Vietnam. European Journal of English Language Teaching, 6(1), 201-240.Available at: http://dx.doi.org/10.46827/ejel.v6i1.3389. 
Hyytinen, H., Löfström, E., \& Lindblom-Ylänne, S. (2016). Challenges in argumentation and paraphrasing among beginning students in educational sciences. Scandinavian Journal of Educational Research, 61(4), 411-429.Available at: https://doi.org/10.1080/00313831.2016.1147072.

Lam, Y. W., Hew, K. F., \& Chiu, K. F. (2018). Improving argumentative writing: Effects of a blended learning approach and gamification. Language Learning \& Technology, 22(1), 97-118.

Latifi, S., Noroozi, O., Hatami, J., \& Biemans, H. J. A. (2021). How does online peer feedback improve argumentative essay writing and learning? Innovations in Education and Teaching International, 58(2), 195-206.Available at: https://doi.org/10.1080/14703297.2019.1687005.

List, A., \& Alexander, P. A. (2018). Toward an integrated framework of multiple text use. Educational Psychologist, 54(1), 2039.Available at: https://doi.org/10.1080/00461520.2018.1505514.

Luna, M., Villalón, R., Mateos, M., \& Martín, E. (2020). Improving university argumentative writing through online training. Journal of Writing Research, 12(1), 233-262.Available at: https://doi.org/10.17239/jowr-2020.12.01.08.

Miller, R. T., \& Pessoa, S. (2016). Where's your thesis statement and what happened to your topic sentences? Identifying organizational challenges in undergraduate student argumentative writing. TESOL Journal, 7(4), 847-873.Available at: https://doi.org/10.1002/tesj.248.

Ministry of Education (MOE). (2015). Executive summary: Malaysia education blueprint 2015-2025 (higher education). Putrajaya: Kementerian Pendidikan Malaysia.

Morris, J. A., Miller, B. W., Anderson, R. C., Nguyen-Jahiel, K. T., Lin, T.-J., Scott, T., \& Ma, S. (2018). Instructional discourse and argumentative writing. International Journal of Educational Research, 90, 234-247.Available at: https://doi.org/10.1016/j.ijer.2018.03.001.

Nejmaoui, N. (2019). Improving EFL learners' critical thinking skills in argumentative writing. English Language Teaching, 12(1), 98-109.Available at: http://dx.doi.org/10.5539/elt.v12n1p98.

Pei, Z., Zheng, C., Zhang, M., \& Liu, F. (2017). Critical thinking and argumentative writing: Inspecting the association among EFL learners in China. English Language Teaching, 1O(10), 31-42.Available at: http://doi.org/10.5539/elt.v10n10p31.

Pratiwi, K. D. (2016). Students' difficulties in writing English (A study at the third semester students of English education program at University of Bengkulu Academic Year 2011-2012). Linguists: Journal of Linguistics and Language Teaching, $3(1), 1-17$.

Reznitskaya, A., Anderson, R. C., McNurlen, B., Nguyen-Jahiel, K., Archodidou, A., \& Kim, S. (2001). Influence of oral discussion on written argument. Discourse Processes, 32(2-3), 155-175.Available at: https://doi.org/10.1080/0163853X.2001.9651596.

Rubiaee, A. M., Darus, S., \& Abu Bakar, N. (2019). The effect of writing knowledge on EFL students' ability in composing argumentative essays. Arab World English Journal, 10(4).Available at: https://dx.doi.org/10.24093/awej/vol 10no4.20.

Shi, Y., Matos, F., \& Kuhn, D. (2019). Dialog as a bridge to argumentative writing. Journal of Writing Research, 11(1), 107129.Available at: https://doi.org/10.17239/jowr-2019.11.01.04

Srinawati, W., \& Alwi, R. (2020). Critical thinking ability in EFL students' argumentative essay writing: The difficulties and the strategies. Science Journal, 21(2), 200-2 10.Available at: https://doi.org/10.32672/si.v2 1i2.2194.

Tahira, M., \& Haider, G. (2019). The role of critical thinking in academic writing: An investigation of EFL students' perceptions and writing experiences. International Online Journal of Primary Education, 8(1), 1-30.

Taylor, K. S., Lawrence, J. F., Connor, C. M., \& Snow, C. E. (2018). Cognitive and linguistic features of adolescent argumentative writing: Do connectives signal more complex reasoning? Reading and Writing, 32, 983-1007.Available at: https://doi.org/10.1007/s $11145-018-9898-6$. 